\title{
Organic compost addition to raw rice husk substrate for tomato (Solanum lycopersicum) hybrid variety cultivation in a leach recirculating system
}

\section{Adición de compost orgánico al sustrato de cáscara de arroz crudo para el cultivo de variedades híbridas de tomate (Solanum lycopersicum) en sistema con recirculación del lixiviado}

\section{FERNANDA CARINI1, 6 \\ ROBERTA MARINS NOGUEIRA PEIL² \\ GABRIEL NACHTIGAL MARQUES ${ }^{3}$ \\ PAULO ROBERTO GROLLI ${ }^{4}$ \\ RAFAELA SCHMIDT DE SOUZA ${ }^{5}$}

Beefsteak tomatoes in substrate cultivation.

Photo: F. Carini

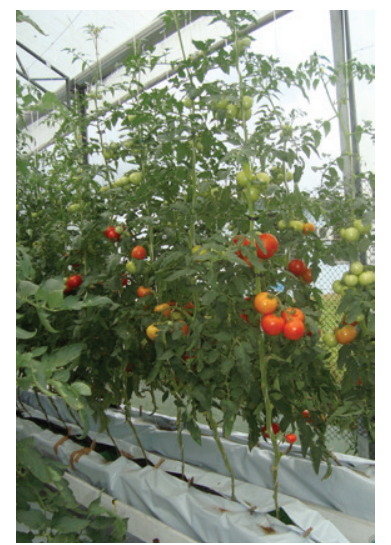

\footnotetext{
ABSTRACT

The addition of organic compost (OC) to raw rice husk (RRH) may benefit the production of a tomato crop by conferring a greater buffer capacity and water holding capacity to the substrate in a leach recirculation system. At the same time, the selection of varieties that respond positively to the proposed technology is required. The objective of this work was to study the effects of adding OC to RRH on the physical and chemical properties of substrate [by comparing RRH (100\%) and the mixture of RRH (80\%) + OC (20\%)] and on growth and yield responses of four tomato hybrid varieties [Ivety, Sofhia-F3, Sheila Victoria, and Lumi (Sakata ${ }^{\circledR}$ Seed)]. The chemical and physical properties of substrates, plant dry matter production and partitioning, fruit number, mean weight and yield, and fruit total soluble solids (TSS) content were evaluated. Fruit grading and harvest distribution along the crop cycle were also performed. The addition of OC improved the physical and chemical properties of the substrate. However, it did not affect the major growth and

1 Faculdade de Agronomia Eliseu Maciel (FAEM), Departamento de Fitotecnia, Programa de Pós-Graduação em Sistemas de Produção Agrícola Familiar, Universidade Federal de Pelotas, Pelotas-RS (Brazil). Bolsista CNPO. ORCID Carini, F: 0000-0001-6000-7747

2 Faculdade de Agronomia Eliseu Maciel (FAEM), Departamento de Fitotecnia, Universidade Federal de Pelotas, Pelotas-RS (Brazil). Bolsista de Produtividade em Pesquisa CNPO. ORCID Peil, R.M.N.: 0000-0002-4855-3638

3 Instituto Federal do Rio Grande do Sul (IFRS), Vacaria-RS (Brazil). ORCID Marques, G.N.: 0000-0002-5531-4475

4 Faculdade de Agronomia Eliseu Maciel (FAEM), Departamento de Fitotecnia, Universidade Federal de Pelotas, Pelotas-RS (Brazil). ORCID Grolli, P.R.: 0000-0002-5695-9072

5 Faculdade de Agronomia Eliseu Maciel (FAEM), Programa de Pós-Graduação em Agronomia, Universidade Federal de Pelotas, Pelotas-RS (Brazil). ORCID Souza, R.S.d.: 0000-0001-7009-3191

6 Corresponding author. carini.fc@gmail.com
} 
productive characteristics of the crop. All four varieties presented similar growth and fruit yield, but Sheila Victoria stood out as having the highest TSS. The yields were considered high, ranging from $6.3 \mathrm{~kg} / \mathrm{plant}$ for Sophya and Sheila Victoria, $6.5 \mathrm{~kg} /$ plant for Lumi, to $7.6 \mathrm{~kg} /$ plant for Ivety. The results indicated that the addition of OC to $\mathrm{RRH}$ is unnecessary and that the four varieties adapted similarly to the proposed system.

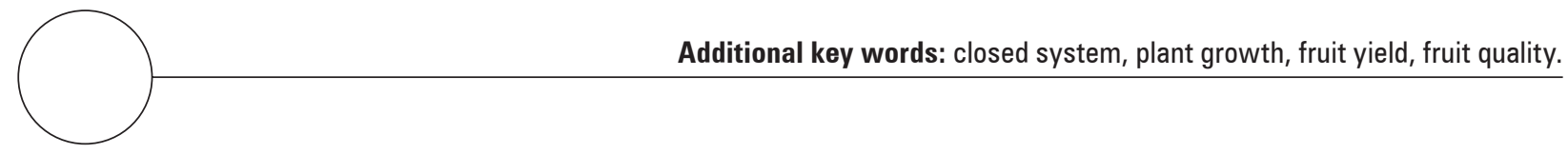

\section{RESUMEN}

La adición de compost orgánico (CO) a la cáscara de arroz cruda (CAC) podría traer beneficios productivos al cultivo del tomate, al conferirle mayor poder buffer y capacidad de retención de agua al sustrato en sistemas con recirculación del lixiviado. Asimismo, es necesaria la elección de variedades que respondan positivamente a la tecnología propuesta. El objetivo del presente trabajo fue estudiar los efectos de la adición del CO a la CAC sobre las características físicas y químicas del sustrato [a través de la comparación entre la CAIN (100\%) y la mezcla de CAC (80\%) + CO $(20 \%)$ ] sobre el crecimiento y el comportamiento productivo de cuatro híbridos de tomate salado [Ivety, Sofhia-F3, Sheila Victoria y Lumi (Sakata ${ }^{\circledR}$ Seed)]. Se evaluaron las características químicas y físicas de los sustratos, la producción (tamaño, número, peso y rendimiento de frutos a lo largo de la cosecha), partición de la materia seca y la concentración de sólidos solubles totales (SST). La adición de CO mejoró las características físicas y químicas del sustrato, pero no afectó las principales variables del crecimiento y de la producción de la hortaliza. Las cuatro variedades presentaron similar crecimiento y rendimiento de frutos pero Sheila Victoria presentó la mayor concentración de SST. El rendimiento obtenido se considera alto, con rangos que van desde $6,3 \mathrm{~kg} /$ planta para las variedades Sophya-F3 y Sheila Victoria, $6,5 \mathrm{~kg} /$ planta para la variedad Lumi, y $7,6 \mathrm{~kg} /$ planta obtenido con la variedad Ivety. Los resultados indican que es innecesaria la adición de CO a la CAC y que las cuatro variedades se adaptan de forma similar al sistema propuesto.

Palabras clave adicionales: sistema cerrado, crecimiento, producción, calidad de fruto.

Received for publication: 28-06-2017 Accepted for publication: 30-01-2018

$\longrightarrow$

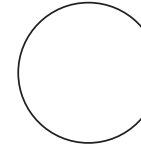

According to FAOSTAT (2012), Brazil is among the ten greatest producers of tomato (Solanum lycopersicum), reaching an annual production of over 3.5 million tons. In the beefsteak tomato segment, fruit quality and a steady supply to the market are factors that may ensure the success of production (Guimarães et al., 2008; Schwarz et al., 2013). In order to achieve high quality fruit yield, the choice of varieties adapted to the region that effectively respond to the technology and management that are used is necessary.

In recent years, among the technologies adopted in the search for better crop production, substrate cultivation under a protected environment has been advancing at an accelerated rate. It reduces the occurrence of soil pathogens, enables the reduction of pesticide applications, increases the efficient use of inputs, and provides more stable harvests (Genuncio et al., 2010; Lúcio et al., 2012).

However, the use of recipients containing commercial substrates or coconut fiber in open cultivation systems (the drained nutrient solution is leached into the environment) is the most common technology adopted by Brazilian farmers. This, in addition to causing a high waste of water and fertilizers, may cause significant environmental impacts.

Thus, the development of closed cultivation systems, i.e. systems that promote the collection and reuse of a drained nutrient solution, is essential. However, 
there is a need to adjust the substrate because materials with both a high cation exchange capacity and high water holding capacity because of the reuse of the drained nutrient solution may cause salinization of the root medium.

Raw rice husk, a low-cost, easily available material in Rio Grande do Sul, has been used alone as a cultivation substrate with a high degree of success for other fruit plants (Duarte et al., 2008; Strassburger et al., 2011), and even for small tomato varieties (Peil et al., 2014) in closed systems. However, the presence of organic compost at a small ratio in the mixture should increase the substrate buffer capacity and facilitate nutrient solution management, increasing water and mineral nutrients storage capacity and, therefore, enhancing crop yield. On the other hand, it could also accelerate the decomposition of the rice husk with negative consequences on the chemical and physical characteristics of the substrate and cause nutritional deficiencies to the crop, particularly nitrogen.

According to Kämpf (2005), the evaluation of the physical and chemical properties of substrates is required to know and select materials that could be used as a substrate, observe the effects of interactions among components, define the irrigation management and monitor fertility.

The objective of this study was to analyze the effects of adding organic compost to raw rice husk in a closed soil-less cultivation system on the physical and chemical properties of the substrate and on the growth and yield responses of four beefsteak tomato hybrid varieties.

\section{MATERIALS AND METHODS}

This study was conducted from July, 2014 to April, 2015 in a $200 \mathrm{~m}^{2}$ plastic greenhouse located at $31^{\circ} 48^{\prime}$ $\mathrm{S}$ and $53^{\circ} 49^{\prime} \mathrm{W}$, with an altitude of $15 \mathrm{~m}$ a.s.l. According to the Köppen classification, the climate corresponded to CFA, humid subtropical with hot summers without a defined dry season. The temperature and air humidity inside the greenhouse during the experiment were recorded, with means of 39.6 and $3.0^{\circ} \mathrm{C}$ of maximum and minimum temperature, and means of 95 and $32 \%$ of maximum and minimum air humidity, respectively.

A randomized block $2 \times 4$ factorial experimental design was used with four replications. The substrate was the first experimental factor, with two levels, and the second was the beefsteak tomato hybrid variety, with four levels. The levels of the factor substrate were raw rice husk used alone (100\%) and a mixture of raw rice husk with organic compost based on orange juice industry waste "Ecocitrus" at a ratio of $80 / 20 \%(\mathrm{v} / \mathrm{v})$. Since there is no previous research on OC addition to RRH for tomato crops, the ratio $80 / 20 \%$ was established based on previous indications for strawberry cultivation in closed soilless growing systems (Marques and Peil, 2016). The levels of the factor variety were Ivety, Sofhia-F3, Sheila Victoria and Lumi (Sakata Seed ${ }^{\circledR}$ ). The substrate factor was allocated to the plot (16 plants) and the variety factor to the subplots (four plants). The experiment was bordered by a row of border plants.

On October 30, 2014, plants with 5-6 true leaves were individually transplanted to $8 \mathrm{~L}$ pots containing $500 \mathrm{~mL}$ of washed gravel on the base and $6 \mathrm{~L}$ of the studied substrates. Previous to the plant setting, the $\mathrm{RRH}$ in a $10 \mathrm{~cm}$ layer was solarized for seven days on the greenhouse floor. Since it was material from a composting process, the OC were considered free of plant plague and pathogens. The pots were placed in 12 wooden growing troughs $(0.35 \mathrm{~m}$ wide and 7.5 $\mathrm{m}$ long), arranged in six double lines, with $1.2 \mathrm{~m}$ between the double lines and $0.50 \mathrm{~m}$ between the single lines. The troughs had a slope of $2 \%$ and were internally waterproofed with double-faced white-black plastic. Two $500 \mathrm{~L}$ tanks were placed at the lowest passage point of the system. In each growing trough, 16 pots were arranged with $0.30 \mathrm{~m}$ plant spacing, resulting in a 3.94 plants $/ \mathrm{m}^{2}$ density.

The solution was adapted from Rocha et al. (2010) for tomato crop. It had the following composition of macronutrients (in $\mathrm{mmol} \mathrm{L}^{-1}$ ): 14.0 of $\mathrm{NO}_{3}^{-} ; 1.15$ of $\mathrm{H}_{2} \mathrm{PO}_{4}^{-} ; 1.75$ of $\mathrm{SO}_{4}^{-2} ; 1.15$ of $\mathrm{NH}_{4}^{+} ; 7.0$ of $\mathrm{K}^{+} ; 3.5$ of $\mathrm{Ca}^{2+}$; 1.75 of $\mathrm{Mg}^{+2}$; and micronutrients (in $\mathrm{Mg} \mathrm{L}^{-1}$ ): 3.0 of Fe; 0.5 of $\mathrm{Mn}$; 0.05 of $\mathrm{Zn} ; 0.15$ of B; 0.02 of $\mathrm{Cu}$; and 0.01 of Mo. The electrical conductivity was kept at $1.8 \mathrm{dS} \mathrm{m}^{-1}$ and the $\mathrm{pH}$ was kept between 5.5 and 6.5 .

The plants were only trained with the main stem and stacked vertically with a plastic stake attached to a wire about $3.0 \mathrm{~m}$ above the crop row. The plants were topped two leaves above the twelfth truss.

Two central plants from each replication were selected for evaluations. The fruits were harvested in a uniform maturation stage (completely red), counted 
and weighed on a balance. The equatorial diameter of the fruits was measured with an analog caliper rule. The fruits were classified according to the CEAGESP Classification Standard (2003), excluding fruits that had cracks, rot spots, blossom-end rot, symptoms of diseases, damage from cold, radial cracks or holes. The soluble solids content was also analyzed with a manual refractometer (Akso Produtos Eletrônicos Ltda., São Leopoldo-RS, Brazil).

The accumulated shoot dry matter of the control plants was assessed at the end of the experiment (167 days after setting; das). The plants were separated into three fractions: leaves, stems and fruits. The leaf area was evaluated using a LI-COR model LI-3000C (LI-COR, Lincoln, NE, USA). The fractions were dried in a forced ventilation oven at $60^{\circ} \mathrm{C}$ until constant weight. The fruits harvested during the production process and the material from defoliation were added to the corresponding fractions. The shoot total dry matter of the plant corresponded to the sum of the masses of leaves, stems and fruits. From these analyses, the dry matter distribution among the aerial organs of the plants and leaf area index of the crop were determined.

The analysis of physical properties of substrates was done at the Laboratory of Substrates for Plants, in Porto Alegre-RS (Brazil). The following parameters were determined: wet density, dry matter, dry density, total porosity, aeration space, easily available water and water holding capacity. The Soil Chemistry Laboratory performed the chemical analyses in Pelotas-RS (Brazil). The following determinations (according the International Growing Media, Composting and Substrate Analysis) were made: organic carbon, total nitrogen, total phosphorus, total potassium, total calcium, total magnesium, total copper, total zinc, total iron, manganese, and $\mathrm{C} / \mathrm{N}$ ratio. For both the physical and chemical properties, three samples of $3 \mathrm{~L}$ of each substrate were analyzed. The samples were collected at two times: at the setting day (0 das), collecting randomized samples from each substrate pile before the plant cultivation; and at end of the crop cycle (168 das), collecting the samples directly from pots chosen at random.

The data were submitted to analysis of the mathematical assumptions (normality and homogeneity), followed by analysis of variance (ANOVA), and the averages were compared with a Tukey test at $5 \%$ significance using Action and Assistat (version 7.7 beta) according to Silva and Azevedo (2002).

\section{RESULTS AND DISCUSSION}

For the physical properties of the substrates at the beginning of the experiment, the addition of organic compost to RRH greatly increased wet density, dry density, easily available water and water holding capacity (Tab. 1). On the other hand, it decreased porosity and practically did not alter the dry matter of the substrate. These changes are basically attributed to the fact that, because it is a thicker organic material with smaller particles, the OC fills the spaces between the particles of rice husk, increasing the water holding capacity by increasing the percentage of micropores.

For both substrates, the analysis at the end of the crop cycle showed that there was a similar reduction

Table 1. Physical properties of the raw rice husk substrates(RRH) and the mixture of raw rice husk with organic compost (RRH $+0 C$ ), zero and 168 days after setting (das) of tomato crop in a closed soilless growing system.

\begin{tabular}{|c|c|c|c|c|}
\hline \multirow{3}{*}{$\begin{array}{l}\text { Physical } \\
\text { properties }\end{array}$} & \multicolumn{4}{|c|}{ Substrates } \\
\hline & \multicolumn{2}{|c|}{$\mathrm{RRH}$} & \multicolumn{2}{|c|}{$\mathrm{RRH}+\mathrm{OC}$} \\
\hline & 0 das & 168 das & 0 das & 168 das \\
\hline Wet density $\left(\mathrm{g} \mathrm{L}^{-1}\right)$ & 114.0 & 108.0 & 282.0 & 275.0 \\
\hline Dry matter (g $\left.100 \mathrm{~g}^{-1}\right)$ & 89.0 & 55.0 & 87.0 & 54.0 \\
\hline Dry density $\left(\mathrm{g} \mathrm{L}^{-1}\right)$ & 102.0 & 59.0 & 246.0 & 148.0 \\
\hline Total porosity $\left(\mathrm{m}^{3} \mathrm{~m}^{-3}\right)$ & 0.85 & 0.73 & 0.79 & 0.77 \\
\hline Aeration space $\left(\mathrm{m}^{3} \mathrm{~m}^{-3}\right)$ & 0.70 & 0.63 & 0.45 & 0.43 \\
\hline Easily available water $\left(\mathrm{m}^{3} \mathrm{~m}^{-3}\right)$ & 0.07 & 0.02 & 0.20 & 0.11 \\
\hline Water holding capacity at $10 \mathrm{~cm}\left(\mathrm{~m}^{3} \mathrm{~m}^{-3}\right)$ & 0.15 & 0.11 & 0.34 & 0.33 \\
\hline
\end{tabular}


in percentage values for wet density, dry density and dry weight. However, the addition of organic compost to the RRH provided a greater physical stability to the substrate since it presented less reduction in porosity values, aeration space, easily available water and water holding capacity in relation to what was verified for the RRH substrate used alone. The greatest reduction in total porosity of the RRH after cultivation was probably due to the decrease in the aeration space that was occupied by the decomposed material or by the breakdown of the structure of the husks during the crop cycle.

The ideal dry density described by Kämpf (2005) for substrates in pots for plants grown in a greenhouse is $150 \mathrm{~g} \mathrm{~L}^{-1}$. The RRH presented a value close to this at the beginning of the crop cycle, while for RRH + OC this occurred only after the end of cultivation.

The easily available water values decreased after cultivation for both substrates. For RRH, the decrease from 0.07 to $0.02\left(\mathrm{~m}^{3} \mathrm{~m}^{-3}\right)$ may have been due to water retention within the husk structure since, during the growth period, it was in constant contact with the nutrition solution, a fact that did not occur at the beginning of the study. For RRH + OC, the reduction of the easily available water percentage $(0.20$ to $0.11 \mathrm{~m}^{3} \mathrm{~m}^{-3}$ ) may have ascribed to the accommodation of the particles of the two materials during plant cultivation, increasing the percentage of micropores that may have retained water at tensions above 100 $\mathrm{cm}$ of water column.

For the chemical properties (Tab. 2), the addition of $\mathrm{OC}$ raised the $\mathrm{pH}$ and electrical conductivity of the substrate at the beginning of crop cycle. The OC fibers retained the nutrient solution more easily, thereby causing an increase of $0.18 \mathrm{dS} \mathrm{m}^{-1}$ in the electrical conductivity of the substrate prior to use, as compared with the isolated RRH.

The $\mathrm{pH}$ values decreased for both substrates at the end of the crop cycle, but more sharply for RRH + OC. This greater $\mathrm{pH}$ decreased for $\mathrm{RRH}+\mathrm{OC}$ may be attributed to a higher material degradation resulting from the presence of the microorganisms from $\mathrm{OC}$ and to the greater need for an acid solution to correct the $\mathrm{pH}$ of this substrate more frequently. Usually, pH values from 5.5 to 6.5 are considered the most suitable for substrates (Fermino, 2014). In the case of the addition to raw rice husk, conditioning materials that have $\mathrm{pH}$ values lower than those presented by the OC used in this research, around 4.0, should be employed to reduce the use of an acid correction solution.

The analysis of the chemical composition of the substrate before cultivation indicated that the addition

Table 2. Chemical composition of the raw rice husk (RRH) and of the mixture of raw rice husk with organic compost (RRH + OC) substrates, zero and 168 days after setting (das) of tomato crop in a closed soilless growing system.

\begin{tabular}{|c|c|c|c|c|}
\hline \multirow{3}{*}{ Chemical properties } & \multicolumn{4}{|c|}{ Substrate } \\
\hline & \multicolumn{2}{|c|}{$\mathrm{RRH}$} & \multicolumn{2}{|c|}{$\mathrm{RRH}+\mathrm{OC}$} \\
\hline & 0 das & 168 das & 0 das & 168 das \\
\hline Electrical conductivity $\left(\mathrm{dS} \mathrm{m}^{-1}\right)$ & 0.06 & 0.23 & 0.24 & 0.61 \\
\hline $\mathrm{pH}\left(\mathrm{H}_{2} \mathrm{O}\right)$ & 6.55 & 6.39 & 7.38 & 6.73 \\
\hline Organic carbon $\left(\mathrm{g} \mathrm{kg}^{-1}\right)$ & 455.46 & 439.62 & 342.00 & 308.88 \\
\hline Nitrogen (\%) & 4.28 & 8.21 & 8.75 & 13.21 \\
\hline Phosphorus (\%) & 0.92 & 0.69 & 2.80 & 4.50 \\
\hline Potassium (\%) & 2.22 & 1.26 & 4.27 & 3.02 \\
\hline Calcium (\%) & 0.88 & 4.51 & 27.55 & 142.30 \\
\hline Magnesium (\%) & 0.67 & 0.84 & 6.48 & 4.03 \\
\hline Copper $\left(\mathrm{mg} \mathrm{kg}^{-1}\right)$ & 6.17 & 6.86 & 23.14 & 28.42 \\
\hline Zinc $\left(\mathrm{mg} \mathrm{kg}^{-1}\right)$ & 9.93 & 9.05 & 29.78 & 48.61 \\
\hline Iron $\left(\mathrm{mg} \mathrm{kg}^{-1}\right)$ & 294.46 & 233.36 & $3,393.15$ & $3,407.79$ \\
\hline Manganese $\left(\mathrm{mg} \mathrm{kg}^{-1}\right)$ & 271.29 & 140.13 & 271.29 & 269.73 \\
\hline Ratio C/N & $106: 1$ & $53: 1$ & $39: 1$ & $23: 1$ \\
\hline
\end{tabular}


of the organic compost to the RRH reduced the level of organic carbon and the $\mathrm{C} / \mathrm{N}$ ratio. However, it elevated the levels of all mineral elements, with special emphasis on calcium and iron.

The analysis of the chemical composition of the substrates after their use indicates that the RRH used alone had a low nutrient adsorption capacity, except for nitrogen and calcium. The increase of calcium and nitrogen can be ascribed to the higher amount of these elements in the nutrient solution. Furthermore, potassium demand was proportionally higher than nitrogen and calcium demand during fruit growth, which resulted in higher levels of both elements in the substrate at the end of crop cycle. The levels of phosphorus, potassium, magnesium, copper, zinc, iron and manganese at the end of cultivation were similar or lower than the initial values. On the other hand, the presence of organic compost in the substrate provided a significant increase in the levels of nitrogen, phosphorus, calcium, copper, and zinc, and reduced potassium and magnesium levels. The microorganism activity of the $\mathrm{OC}$ enhanced the decomposition of the organic material, which possibly increased the availability of some elements. Moreover, the colloidal characteristics of the OC benefited the adsorption of ions. The decreased of potassium and magnesium suggests the use of these elements for the nutrition of microorganisms themselves. The level of iron remained virtually unchanged in the RRH + OC substrate. The data indicated that the organic compost provided a greater retention of chemical elements when compared with the final RRH values.

According to Fermino (2014), organic compost is the result of a process of composting of plant or animal waste; specifically, in this case, waste from the processing industry of oranges (juice). The composting process decomposes organic matter, facilitating the release of nutrient elements and forming colloids that increase the cation exchange capacity of the substrate, favoring the adsorption of elements. The higher density of the RRH + OC mixture, along with its chemical composition and the presence of colloids, increased the initial nutrient levels and the nutrient retention process. However, in the case of growing in a substrate reusing the drain solution, these characteristics may hinder the management of the nutrient solution because of strong changes in its composition resulting from the influence of the compost. It may even present salinity problems in longer cycles, making it difficult to reuse the substrate in successive crop cycles.
The analysis of variance indicated that there was no significant interaction between the substrate and variety factors for all of the analyzed growth and productive variables. The interaction was statistically significant only for the factors substrate $\mathrm{x}$ class and cultivar $\mathrm{x}$ class in the classification of the fruits according to the CEAGESP Classification Standard (2003).

For the plant growth results (Tab. 3), the addition of $O C$ to the RRH increased production of leaf dry matter (DM), the proportional dry matter partitioning to the leaves and the leaf area index (LAI). However, it did not affect fruit and stem DM production and partitioning.

The varieties did not differ statistically for fruit DM production. However, the Ivety variety was superior to the others for leaf DM and, together with Sheyla, for stem DM production. Nevertheless, the varieties did not differ in LAI, total plant DM production or proportional DM partitioning for fruits. The fruits accounted for $58-64 \%$ of DM produced by the shoot, coinciding with the results previously obtained for other beefsteak tomato varieties (Andriolo et al., 2003; Aguirre et al., 2012; Lucena et al., 2013; Soares et al., 2013). The fruits can be considered as the most powerful photoassimilate sink. This is a decisive factor for planning and choosing varieties since their productive performance is a direct response to a higher proportion of assimilates accumulated in the fruits.

For the fruit production variables fruit number, fruit mean weight, marketable yield and fruit total soluble solid contents (Tab. 4), it was found that the addition of organic compost caused no significant effects. Different responses among varieties for these variables were also not observed, except for total soluble solid contents (TSS): the variety Sheila Victoria, with $5.0^{\circ} \mathrm{Brix}$, was superior to Sophya (4.5 ${ }^{\circ}$ Brix) and Lumi (4.6 ${ }^{\circ}$ Brix) varieties, without differing from the Ivety $\left(4.8^{\circ} \mathrm{Brix}\right)$ variety. The responses resemble those of Genuncio et al. (2010), who observed that only TSS statistically differed among the evaluated fruit production variables of three beefsteak tomato varieties. According to Alvarenga (2013), the TSS contents of fresh tomatoes usually remain between 3.0 and $4.5^{\circ} \mathrm{Brix}$. Previous results for fruits produced in open field conditions indicate values of $3.8^{\circ} \mathrm{Brix}$ for the variety Santa Clara (Ferreira et al., 2006) and $4^{\circ}$ Brix for the variety Fanni F1 (Guimarães et al., 2008). The high TSS values found for the varieties described in this study refer to fruits 
Table 3. Effects of organic compost (OC) addition to the raw rice husk (RRH) substrate and the tomato beefsteak variety on the production and dry matter partitioning among the different above-ground organs and leaf area index (LAI) of plants grown in a closed soilless system.

\begin{tabular}{|c|c|c|c|c|c|c|c|c|}
\hline \multirow{2}{*}{ Factor } & \multicolumn{4}{|c|}{ Dry matter production (g/plant) } & \multicolumn{3}{|c|}{ Dry matter partitioning (\%) } & \multirow[b]{2}{*}{ LAI } \\
\hline & Fruits & Leaves & Stem & Total & Fruits & Leaves & Stem & \\
\hline \multicolumn{9}{|l|}{ Substrate } \\
\hline RRH & $370.9 \mathrm{a}$ & $131.7 b$ & $100.2 \mathrm{a}$ & $588.7 \mathrm{a}$ & $61.0 \mathrm{a}$ & $21.9 b$ & $17.1 \mathrm{a}$ & $3.14 b$ \\
\hline $\mathrm{RRH}+\mathrm{OC}$ & $367.2 \mathrm{a}$ & $151.6 \mathrm{a}$ & 99.7 a & 603.3 a & $59.0 \mathrm{a}$ & $24.5 \mathrm{a}$ & $16.5 \mathrm{a}$ & $4.34 \mathrm{a}$ \\
\hline \multicolumn{9}{|l|}{ Variety } \\
\hline Ivety & $412.6 \mathrm{a}$ & $185.8 \mathrm{a}$ & $101.6 \mathrm{a}$ & $700.3 \mathrm{a}$ & $58.5 \mathrm{a}$ & $26.8 \mathrm{a}$ & $14.7 b$ & $4.14 \mathrm{a}$ \\
\hline Sophya & $384.6 \mathrm{a}$ & $112.8 b$ & $96.9 \mathrm{~b}$ & $564.8 \mathrm{a}$ & $64.0 \mathrm{a}$ & $19.2 b$ & $16.8 \mathrm{ab}$ & $3.13 \mathrm{a}$ \\
\hline Sheila Victoria & $336.2 \mathrm{a}$ & $133.8 \mathrm{~b}$ & $101.5 \mathrm{a}$ & $560.7 \mathrm{a}$ & $58.2 \mathrm{a}$ & $23.6 \mathrm{ab}$ & $18.2 \mathrm{a}$ & $4.53 \mathrm{a}$ \\
\hline Lumi & $342.8 \mathrm{a}$ & $134.3 \mathrm{~b}$ & $99.8 a b$ & $558.1 \mathrm{a}$ & $59.4 \mathrm{a}$ & $23.2 \mathrm{ab}$ & $17.4 \mathrm{ab}$ & $3.16 \mathrm{a}$ \\
\hline CV (\%) & 24.4 & 15.7 & 2.5 & 17.1 & 8.2 & 14.1 & 15.0 & 28.6 \\
\hline
\end{tabular}

Means followed by identical letters in the same column did not differ according to the Tukey test $(P \leq 0.05)$.

Table 4. Effect of organic compost addition (OC) to the raw rice husk (RRH) substrate and beefsteak tomato variety on the number, mean weight, marketable yield and total soluble solid contents (TSS) of fruits in a closed soilless growing system.

\begin{tabular}{|l|c|c|c|c|}
\hline \multicolumn{1}{|l|}{ Factor } & Númber of fruits/plant & $\begin{array}{c}\text { Fruit mean weight } \\
\text { (g/fruit) }\end{array}$ & $\begin{array}{c}\text { Marktable yield } \\
\text { (g/plant) }\end{array}$ & SST ('Brix) \\
\hline Substrate & $50.8 \mathrm{a}$ & $129.4 \mathrm{a}$ & $6,637.3 \mathrm{a}$ & $4.8 \mathrm{a}$ \\
\hline RRH & $48.8 \mathrm{a}$ & $133.2 \mathrm{a}$ & $6,731.6 \mathrm{a}$ & $4.7 \mathrm{a}$ \\
\hline RRH+OC & \multicolumn{5}{|c|}{} \\
\hline Cultivar & $50.9 \mathrm{a}$ & $135.4 \mathrm{a}$ & $7,656.4 \mathrm{a}$ & $4.8 \mathrm{ab}$ \\
\hline Ivety & $53.5 \mathrm{a}$ & $118.7 \mathrm{a}$ & $6,299.1 \mathrm{a}$ & $4.5 \mathrm{~b}$ \\
\hline Sophya & $45.6 \mathrm{a}$ & $137.2 \mathrm{a}$ & $6,311.1 \mathrm{a}$ & $5.0 \mathrm{a}$ \\
\hline Sheila Victoria & $49.1 \mathrm{a}$ & $133.5 \mathrm{a}$ & $6,471.1 \mathrm{a}$ & $4.6 \mathrm{~b}$ \\
\hline Lumi & 15.0 & 11.1 & 17.4 & 0.3 \\
\hline CV (\%) &
\end{tabular}

Means followed vertically by identical letters did not differ according to the Tukey test $(P \leq 0.05)$.

harvested during the full red coloring or deep red stages, in which the physiological processes occur naturally. According to Paula et al. (2015), fruits harvested with a yellowish-green tinge have a longer postharvest life and a higher resistance to transport. However, fruits have better characteristics for taste quality when they complete their maturation (red stage) while still on the plant.

The mean fresh weight of the fruits was below the range $210-230 \mathrm{~g}$. This is the range reported by the seed breeding company for the evaluated varieties in field trials. It shows that new adaptations of the growing system and/or the crop management may be necessary for the studied varieties to fully expose their genetic potential. However, the marketable yield may be considered quite high, ranging from $6.3 \mathrm{~kg} /$ plant $\left(248.2 \mathrm{t} \mathrm{ha}^{-1}\right)$ for the Sophya and Sheila Victoria varieties, $6.5 \mathrm{~kg} /$ plant $\left(256.1 \mathrm{t} \mathrm{ha}^{-1}\right)$ for the Lumi variety, to $7.6 \mathrm{~kg} /$ plant $\left(299.4 \mathrm{t} \mathrm{ha}^{-1}\right)$ for the Ivety variety. Other studies using soilless cultivation systems reported a production of $3.3 \mathrm{~kg} /$ plant for both the Monte Carlo variety grown in organic substrate (Plantmax ${ }^{\circledR}$ Company, Brazil) (Rattin et al., 2003) and the Santa Clara variety grown in a hydroponic system (Genuncio et al., 2010). Lima et al. (2011) obtained a fruit yield of $5.7 \mathrm{~kg} /$ plant for the Venus variety grown in a coconut fiber substrate. 
Tables 5 and 6 show the percentage classification of the fruits according to the equatorial diameter, considering the substrate $\mathrm{x}$ class effect and class $\mathrm{x}$ cultivar effect, respectively.

The fruit standard required by the Brazilian market excludes fruits with a diameter less than $40 \mathrm{~mm}$ and greater than $100 \mathrm{~mm}$ (Paula, 2015). The intermediate classes are preferred because of their convenience during the preparation of food. All fruits without defects obtained in the experiment were within the commercial classes (40-99 $\mathrm{mm})$.

The addition of the organic compost to the substrate increased the percentage of fruits in class 70 , with a reduction of fruits in class 50 . This did not interfere with the percentage of fruits from other classes (Tab. 5).

All of the tested varieties presented the highest percentage of fruits in class 60 , with no statistical differences. In this class, the percentage varied from 49.1 to $64.9 \%$ (Tab. 6). Thus, most of the harvested fruits can be considered as having a medium size according to the classification proposed by Andreuccetti et al. (2004) for Debora and Carmen beefsteak varieties.
Approximately $80 \%$ of the fruits of the Ivety and Sheila Victoria varieties remained in classes 60 and 70. However, most Sophya and Lumi fruits remained in classes 50 and 60.

Despite the presence of physical and chemical properties that are considered more suitable for a standard substrate provided by the organic compost (Kämpf, 2005), there was no significant effect on most of the analyzed growth variables or fruit production characteristics (Tab. 4). This may be attributed to the high frequency of nutrient solution supply imposed by a low water holding capacity of the RRH substrate (Tab. 1), which provided adequate amounts of water and nutrients. The high frequency of irrigation is not a problem in recirculating systems since the leach solution is reused. There is, however, a greater expenditure of electric power. Moreover, the fact that the organic compost is not needed is beneficial since this material is usually expensive and makes more difficult to manage the nutrient solution. Moreover, its composition varies. On the other hand, in the case of growers with electrical distribution irregularities, the substrate with the addition of organic compost may favor the retention of water, which is more suitable to the crop over a longer period.

Table 5. Classification percentage based on the equatorial diameter of the beefsteak tomato fruits grown in the raw rice husk (RRH) and the mixture of RRH and organic compost (RRH + OC) substrate in a closed soilless cultivation system.

\begin{tabular}{|l|c|c|c|c|c|c|c|c|}
\hline \multirow{2}{*}{ Substrate } & \multicolumn{10}{c|}{ Class } \\
\cline { 2 - 10 } & 0 & 40 & 50 & 60 & 70 & 80 & 90 & 100 \\
\hline RRH & $0.0 \mathrm{aG}$ & $2.3 \mathrm{aD}$ & $21.8 \mathrm{aB}$ & $59.7 \mathrm{aA}$ & $14.6 \mathrm{bC}$ & $1.3 \mathrm{aE}$ & $0.5 \mathrm{aF}$ & $0.0 \mathrm{aG}$ \\
\hline $\mathrm{RRH}+\mathrm{OC}$ & $0.0 \mathrm{aG}$ & $2.3 \mathrm{aD}$ & $16.9 \mathrm{bC}$ & $56.8 \mathrm{bA}$ & $22.1 \mathrm{aB}$ & $1.3 \mathrm{aE}$ & $0.8 \mathrm{aF}$ & $0.0 \mathrm{aG}$ \\
\hline
\end{tabular}

Classes express the equatorial diameter (mm): 0 (smaller than $40 \mathrm{~mm}$ ), 40 ( $\geq 40$ up to 50 ), 50 ( $\geq 50$ up to 60 ), 60 ( $\geq 60$ up to 70 ), 70 ( $\geq 70$ up to 80 ), 80 ( $\geq$ 80 up to 90$), 90$ ( $\geq 90$ up to 100$)$ and $100(>100)$.

Means followed vertically by identical lowercase letter and horizontally by capital letters did not differ statistically according to the Tukey test $(P \leq 0.05)$.

Table 6. Classification percentage based on the fruit equatorial diameter of four hybrid varieties of beefsteak tomato grown in a closed substrate cultivation system.

\begin{tabular}{|l|c|c|c|c|c|c|c|c|}
\hline \multirow{2}{*}{\multicolumn{1}{|c|}{ Variety }} & \multicolumn{9}{c|}{ Class } \\
\cline { 2 - 10 } & 0 & 40 & 50 & 60 & 70 & 80 & 90 & 100 \\
\hline Ivety & $0.0 \mathrm{aG}$ & $1.5 \mathrm{dD}$ & $9.5 \mathrm{dC}$ & $61.4 \mathrm{bA}$ & $24.9 \mathrm{aB}$ & $1.3 \mathrm{bE}$ & $1.3 \mathrm{aE}$ & $0.0 \mathrm{aG}$ \\
\hline Sophya & $0.0 \mathrm{aG}$ & $3.6 \mathrm{aD}$ & $33.6 \mathrm{aB}$ & $49.3 \mathrm{dA}$ & $12.3 \mathrm{dC}$ & $1.2 \mathrm{cE}$ & $0.5 \mathrm{bF}$ & $0.0 \mathrm{aG}$ \\
\hline Sheila Victoria & $0.0 \mathrm{aG}$ & $2.3 \mathrm{bD}$ & $17.9 \mathrm{bC}$ & $57.4 \mathrm{cA}$ & $20.2 \mathrm{bB}$ & $1.9 \mathrm{aE}$ & $0.5 \mathrm{bF}$ & $0.0 \mathrm{aG}$ \\
\hline Lumi & $0.0 \mathrm{aG}$ & $2.02 \mathrm{cD}$ & $16.39 \mathrm{cB}$ & $64.9 \mathrm{aA}$ & $15.9 \mathrm{cC}$ & $0.8 \mathrm{dE}$ & $0.5 \mathrm{bF}$ & $0.0 \mathrm{aG}$ \\
\hline
\end{tabular}

Classes express the equatorial diameter $(\mathrm{mm}): 0$ (smaller than $40 \mathrm{~mm}$ ), 40 ( $\geq 40$ up to 50 ), 50 ( $\geq 50$ up to 60 ), 60 ( $\geq 60$ up to 70 ), 70 ( $\geq 70$ up to 80 ), 80 ( $\geq$ 80 up to 90$), 90$ ( $\geq 90$ up to 100 ) and 100 (> 100).

Means followed vertically by identical lowercase letter and horizontally by capital letters did not differ statistically according to the Tukey test $(P \leq 0.05)$. 


\section{CONCLUSIONS}

The addition of organic compost to raw rice husk improves the physical and chemical properties of the substrate. However, it does not affect the main growth and fruit production characteristics of the crop. Therefore, it is unnecessary for the closed soilless growing system conditions under which the experiment was conducted. The four hybrid varieties of beefsteak tomato evaluated in this study (Ivety, Sheila Victoria, Sophya and Lumi) presented similar fruit growth and production, but Sheila Victoria stood out because it produced fruits with the highest soluble solids content. The obtained yields were considered high, indicating that all four varieties are adapted to the proposed system.

Conflict of interests: the manuscript was prepared and reviewed with the participation of the authors, who declare that there exists no conflict of interest that puts in risk the validity of the presented results.

\section{BIBLIOGRAPHIC REFERENCES}

Aguirre, N.C. and F.A.V. Cabrera. 2012. Evaluating the fruit production and quality of cherry tomato (Solanum lycopersicum var. cerasiforme). Rev. Fac. Nac. Agron. Medellín. 65(2), 6599-6610.

Alvarenga, M.A.R. 2013. Tomate: produção em campo, em casa-de-vegetação e em hidroponia. $2^{\text {th }}$. ed. UFLA, Lavras-MG, Brazil.

Andreuccetti, C., M.D. Ferreira, A.S.D. Guitierrez, and M. Tavares. 2004. Classificação e padronização dos tomates cv. Carmem e Débora dentro da CEGESP-SP. Eng. Agríc. 24(3), 790-798. Doi: 10.1590/ S0100-69162004000300033

Andriolo, J.L., M. Wilter, T. Dal Ross, and R.S. Godói. 2003. Crescimento e desenvolvimento do tomateiro cultivado em substrato com reutilização da solução nutritiva drenada. Hort. Bras. 21(3), 485-489. Doi: 10.1590/ S0102-05362003000300015

CEAGESP. 2003. Norma de classificação do tomate. COC/ CEAGESP, São Paulo-SP, Brazil.

Duarte, T.S., R.M.N. Peil, S. Bacchis, and A.S. Strasburguer. 2008. Efeito da carga de frutos e concentrações salinas no crescimento do meloeiro cultivado em substrato. Hortic. Bras. 26(3), 348-353. Doi: 10.1590/ S0102-05362008000300011

FAOSTAT (Food and Agriculture Organization of the United Nations). 2012. In: http://faostat.fao.org/ site/339/default.aspx; consulted: August, 2016.
Fermino, M.H. 2014. Substratos: composição, caracterização e métodos de análise.: Agrolivros Guaíba, Porto Alegre-RS, Brazil.

Ferreira, M.M.M., G.B. Ferreira, P.C.R. Fontes, and J.P. Dantas. 2006. Qualidade do tomateiro em função de doses de nitrogênio e da adubação orgânica em duas estações. Hortic. Bras. 24(2), 141-145. Doi: 10.1590/ S0102-05362006000200003

Genuncio, G.C., R.A.C. Silva, N.M, SÁ. E. Zonta, and A. P. Araújo. 2010. Produção de cultivares de tomateiro em hidroponia e fertirrigação sob razões de nitrogênio e potássio. Hortic. Bras. 28(4), 446-452. Doi: 10.1590/ S0102-05362010000400012

Guimarães, M.A., J.H., Silva, P.C.R Fontes, and A.P. Mattedi. 2008. Produtividade e sabor dos frutos de tomate do grupo salada em função de podas. Bioscience J. 24(1), 32-38.

Kämpf, A.N. 2005. Produção comercial de plantas ornamentais. $2^{\text {th }}$. ed. Agrolivros Guaíba, Porto Alegre-RS, Brazil.

Lima, A.A., M.A.R. Alvarenga, L. Rodrigues, and J.G. Carvalho. 2011. Concentração de nutrientes e produtividade de tomateiro cultivado sob diferentes substratos e doses de ácido húmico. Hortic. Bras. 29(1), 63-69. Doi: 10.1590/S010205362011000100011

Lucena, R.R.M., M.Z. Negreiros, J.F. Medeiros, T.M.V. Batista, A.T.M. Bessa, and W.A.R. Lopes. 2013. Acúmulo de massa seca e nutrientes pelo tomateiro 'SM - 16 'cultivado em solo com diferentes coberturas. Hortic. Bras. 31(3), 401-409. Doi: 10.1590/ S0102-05362013000300010

Lúcio, A.D., F.M. Haesbaert, D. Santos, D.V. Schwertner, and R. R. Brunes. 2012. Tamanhos de amostra e de parcela para variáveis de crescimento e produtivas de tomateiro. Hortic. Bras. 30(4), 660-668. Doi: 10.1590/ S0102-05362012000400016

Marques, G.N. and R.M N. Peil. 2016. Sistemas de cultivo aberto e fechado. In: Rampazzo, E.F. (ed.). Cultivo de morangueiro em substrato. SENAR-PR, Curitiba-PR, Brazil.

Paula, J.T., J.T.V. Resende, M.V. Faria, A.S.T. Figueiredo, K. Schwarz, and E.R. Neumann. 2015. Características físico-químicas e compostos bioativos em frutos de tomateiro colhidos em diferentes estádios de maturação. Hortic. Bras. 33(4), 434-440 Doi: 10.1590/ S0102-053620150000400005

Peil, R.M.N., A.A.R. Albuquerque Neto, and C. V. Rombaldi. 2014. Densidade de plantio e genótipos de tomateiro cereja em sistema fechado de cultivo em substrato. Hortic. Bras. 32(2), 234-240. Doi: 10.1590/ S0102-05362014000200021

Rattin, J.E., J.L. Andriolo, and M. Witter. 2003. Acumulação de massa seca e rendimento de frutos de tomateiro cultivado em substrato com cinco doses de solução nutritiva. Hortic. Bras. 21(1), 26-30. Doi: 10.1590/ S010205362003000100005 
Rocha, M.Q., R.M.N. Peil, and C. M. Cogo. 2010. Rendimento do tomate cereja em função do cacho floral e da concentração de nutrientes em hidroponia. Hortic. Bras., 28(4), 466-471. Doi: 10.1590/ S0102-05362010000400015

Schwarz, K., J.T.V. Resende, A.P. Preczenhak, J.T. Paula, and D.M. Dias. 2013. Desempenho agronômico e qualidade físico-química de híbridos de tomateiro em cultivorasteiro. Hortic. Bras. 31(3), 410-418. Doi: 10.1590/ FS0102-05362013000300011

Silva, F. de S. and C.A.V. de Azevedo. 2002. Versão do programa computacional ASSISTAT para o sistema operacional Windows. Rev. Bras. Prod. Agroind. 4(1), 71-78. Doi: 10.15871/1517-8595/rbpa.v4n1p71-78

Soares, M.A., M.Z. Negreiros, A.R.L. Welder, J.L.D. Dombroski, and R.R.M. Lucena. 2013. Crescimento do tomateiro cultivado em solo coberto com polipropileno preto. Rev. Ciênc. Agron. 44(4), 790-797. Doi: 10.1590/S1806-66902013000400016

Strassburger, A.S., R.M.N. Peil, L.A. Fonseca, T.Z. Aumonde, and C.R. Mauch. 2011. Dinâmica do crescimento da abobrinha italiana em duas estações de cultivo. Acta Scientiarum 33(2), 283-289. Doi: 10.4025/actasciagron.v33i2.5952 